\title{
Synthesis, Characterization of Novel Benzothiophene Veerappan Jeyachandranan*
}

Department of Chemistry, Bharath Institute of Higher Education and Research, Selaiyur, Chennai, Tamil Nadu, India

*Corresponding author e-mail: jeyorg@gmail.com

\section{ABSTRACT}

\section{Article Info}

Volume 8, Issue 1

Page Number: 38-41

Publication Issue :

January-February-2021

Article History

Accepted : 01 Jan 2021

Published : 06 Jan 2021
A library of novel benzo[ $b]$ thiophenehave been synthesized regioselectively in good yields through the one-pot domino reactions of thiophenone, malononitrile and aromatic aldehydes in the presence of NaOEt. This transformation presumably involves Knoevenagel condensation-Michael addition-intramolecular Thorpe-Ziegler cyclization-TautomerizationElimination sequence of reactions.

Keywords : Ant-Iinflammatory, Thiophenone, Sertaconazole And Asthma.

\section{INTRODUCTION}

Benzo[ $b]$ thiophene derivatives are found within the structural core of several biologically active compounds, for example, raloxifene $\mathrm{TM}^{\mathrm{TM}}$ is a selective estrogen receptor modulator for the prevention of osteoporosis in postmenopausal women [1] and zileuton ${ }^{\mathrm{TM}}$ is an active inhibitor of 5-lipoxygenase used to prevent difficulty in breathing, wheezing and coughing due to asthma and sertaconazole has several known mechanisms of action (Figure1) [2].<smiles>N#Cc1c(N)c(C#N)c2c(c1Br)SC([Al])C2</smiles>

Figure1. Benzo[ $b]$ thiophene derivatives synthesized in the present work

Other pharmacological applications of benzo[ $b]$ thiophene derivatives include estrogen receptor antagonists,[3] antifungal,[4] anti-inflammatory[5] and antimitotic[6] agents. The above significance of benzo[b]thiophene derivatives has set path to several investigations leading to their synthesis and biological activity studies [7]. 
Several other molecular entities containing benzothiophene core are at various stages of development. They include T588 [8] a cognition enhancing agent with potential application for treating Alzheimer's dementia; LY353381 [9] an additional SERM from Lilly; AP521 [10] with potent 5Ht1A receptor binding ability; CI959 [11] an anti-inflammatory agent; and B428 [12] a urokinase inhibitor. Another structurally interesting compound is PD144795 [13] an endothelial cell activation inhibitor as a benzothiophene oxide (Figure3).<smiles>CCCCCO[C@H](O)c1ccc2sccc2c1</smiles>

T588<smiles>CC(C)c1c(C(=O)Nc2nnc[nH]2)sc2ccccc12</smiles>

CI959<smiles>COc1ccc(-c2sc3cc(O)ccc3c2Oc2ccc(OCCN3CCCCC3)cc2)cc1</smiles>

LY353381<smiles>N=C(N)c1cc2c(I)cccc2s1</smiles><smiles>O=C(NCc1ccc2c(c1)OCO2)C1Cc2c(sc3ccccc23)CN1</smiles>

AP521<smiles>COc1ccc2sc(C(N)=O)c(C(C)O)c2c1</smiles>

PD144795

Figure3. Benzothiophenes Various stages of development

In view of the importance of benzothiophene derivatives, herein we report a domino protocol for the regioselective synthesis of a library of highly functionalized novel 5-amino-2,7-diaryl-2,3dihydrobenzo[ $b$ ]thiophene-4,6-dicarbonitriles 4in good yields through the one-pot four-component reactions of 5-aryldihydro-3(2H)-thiophenones1, malononitrile2 and aromatic aldehydes 3in the presence of morpholine (Scheme 1).<smiles>O=C1CCSC1</smiles>

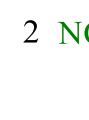

2

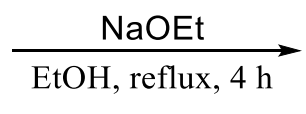

3<smiles>N#Cc1c(N)c(C#N)c2c(c1[Al])CCS2</smiles>

4

Scheme 1. Synthesis of 2,3-dihydrobenzo[ $b]$ thiophene-4,6-dicarbonitriles4

\section{Structure elucidation}

The structure of all the Benzo[b]thiophenes 4 were elucidated unambiguously with the help of one and twodimensional NMR spectroscopy. As a representative case, the ${ }^{1} \mathrm{H}$ and ${ }^{13} \mathrm{C}$ NMR chemical shift assignment of $4 \mathbf{r}$ are discussed. 
In the ${ }^{1} \mathrm{H}$ NMR spectra of $4 \mathrm{r}$, the 2-CH and the 5- $\mathrm{NH}_{2}$ protons overlap and appear as a multiplet at 5.01-5.08 ppm. The $\mathrm{D}_{2} \mathrm{O}$ exchange experiment reveals that the $\mathrm{H}-2$ appears as a triplet at $5.04 \mathrm{ppm}(J=8.4 \mathrm{~Hz})$ and the latter appears as a broad singlet at $5.08 \mathrm{ppm}$.

Table 2. Yield and melting point of Benzo[b]thiophene4

\begin{tabular}{ccccc}
\hline Entry & Comp & $\mathrm{Ar}^{\prime}$ & Yield of 4 (\%) & $\mathrm{mp}\left({ }^{\circ} \mathrm{C}\right)$ \\
\hline 1 & $4 a$ & $4-\mathrm{MeC}_{6} \mathrm{H}_{4}$ & 79 & $165-167$ \\
2 & $4 \mathrm{~b}$ & $4-\mathrm{MeOC}_{6} \mathrm{H}_{4}$ & 85 & $167-169$ \\
3 & $4 \mathrm{c}$ & $4-\mathrm{ClC}_{6} \mathrm{H}_{4}$ & 72 & $175-177$ \\
4 & 4d & $4-\mathrm{FC}_{6} \mathrm{H}_{4}$ & 73 & $157-1159$ \\
\hline
\end{tabular}

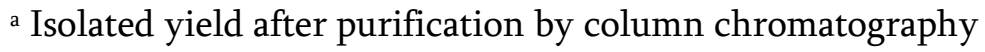

\section{CONCLUSION}

The present investigation reports a one-pot domino protocol for the regioselective synthesis of novel Benzo[b]thiophene via Knoevenagel condensation-Michael addition-intramolecular Thorpe-Ziegler cyclization-Tautomerization-Elimination sequence of reactions.

This four-component reaction results in the formation of four new $\mathrm{C}-\mathrm{C}$ bonds in a single operation. The structure of all the Benzo[ $b]$ thiophene was elucidated with NMR and single crystal X-ray studies.

\section{III.CONFLICT OF INTEREST}

The authors declare no conflict of interest.

\section{IV.ACKNOWLEDGMENTS}

The encouragement and support from Bharath University, Chennai is gratefully acknowledged. For provided the laboratory facilities to carry out the research work.

\section{REFERENCES}

[1]. Marketed as Evista ${ }^{\circledR}$ (Raloxifene Hydrochloride $60 \mathrm{mg}$ ). Grese, T.A.; Dodge, J. A.; Curr. Pharm. Des.,1998, 4, 71.

[2]. Carter, G. W.; Young, P. R.; Albert, D. H.; Bouska, J.;Dyer, R.; Bell, R. L.; Summers, J. B.; Brooks, D. W.J. Pharmacol. Exp. Ther.,1991, 256, 929.

[3]. Palkowitz, A.D.; Glasebrook, A. L.; Thrasher, K. J.; Hauser, K. L.; Short, L. L.; Phillips, D. L.; Muehl, B. S.; Sato, M.; Shetler, P. K.; Cullinan, G. J.; Pell, T. R.; Bryant, H. U. J. Med. Chem.,1997, 40, 1407; (b) Magarian, R. A.; Overacre, L. B.; Singh, S.; Meyer, K. L. Curr.Med. Chem.,1994, 1, 61. 
[4]. Thesen, R. Pharm. Ztg.,1995, 140, 44.

[5]. Bleavins, M. R.; Igelsia, F. A.; McCay, J. A.; White, L.;Kimber, L.; Munson, A. E. Toxicology, 1995, 98, 111.

[6]. Zhang, S.X.; Bastow, K. F.; Tachibana, Y.; Kuo, S.C.; Hamel, E.; Mauger, A.; Narayanan, V. L.; Lee, K.H. J. Med. Chem.,1999, 42, 4081.

[7]. Shedid, S. A. M.; Hassan, H. M.; Kora, F. A.; El-Eisawy, R. M. J. Chem. Pharm. Res.,2011, 3, 388; (b) Isloor, A. M.; Kalluraya, B.; Sridhar, P. K. Eur. J. Med. Chem.,2010, 45, 825; (c) Radwan, M. A. A; Shehab, M. A.; El-Shenawy, S. M. Monatsh Chem.,2009, 140, 445

[8]. Ono, S.; Yamafuji, T.; Chaki, H.; Todo, Y.; Maekawa, M.; Kitamura, K.; Kimura, T.; Nakada, Y.; Mozumi, K.; Narita, H. Biol. Pharm. Bull.,1995, 18, 1779-1783.

[9]. Sato, M.; Turner, C. H.; Wang, T.; Adrian, M. D.; Rowley, E.; Bryant, H. U. J. Pharmacol. Exp. Ther.,1998, 287, 1-7.

[10]. Sorbera, L. A.; Leeson, P.; Castaner, J. Drugs Fut.,1999, 24, 740.

[11]. Wright, C. D; Stewart, S. F.;Kuipers, P. J.;Hoffman, M. D.;Devall, L. J.;Kennedy, J. A.;Ferin, M. A.;Thueson, D. O.;Conroy, M. C. J. Leukoc. Biol.,1994, 55, 443-451.

[12]. Towle, M. J.;Lee, A.;Maduakor, E. C.;Schwartz, C. E.;Bridges, A. J.;Littlefield, B. A. Cancer Res.,1993, 53, 2553-2559.

[13]. Carballo, M.;Conde, M.;Tejedo, J.;Gualberto, A.;jimenez, J.;Monteseirín, J.;Santa María, C.;Bedoya, F. J.;Hunt, S. W. 3rd.;Pintado, E.;Baldwin, A. S. Jr.;Sobrino, Fr. Mol. Genet. Metab.,2002, 75, 360-368.

\section{Cite this article as :}

Veerappan Jeyachandranan, "Synthesis, Characterization of Novel Benzothiophene", International Journal of Scientific Research in Science and Technology (IJSRST), Online ISSN : 2395-602X, Print ISSN : 2395-6011, Volume 8 Issue 1, pp. 38-41, January-February 2021. Available at doi : https://doi.org/10.32628/IJSRST207669 Journal URL : http://ijsrst.com/IJSRST207669 